\title{
Pastoral plants for rehabilitation of degraded soil in Tunisia: the case for use of Calicotome villosa and Genista spachiana (Fabaceae)
}

\author{
Mechergui Kaouther ${ }^{1,2^{*}}$, \\ Jaouadi Wahbi ${ }^{1,2}$, \\ Khouja Mohamed Larbi ${ }^{1}$ \\ ${ }^{1}$ Laboratory of Forest Ecology, \\ National Research Institute \\ of Rural Engineering, \\ Water and Forestry (INRGREF), \\ Rue HediKaray B.P. $N^{\circ} 10$ \\ Ariana 2080, Tunisia \\ ${ }^{2}$ The Sylvo-Pastoral \\ Institute of Tabarka, \\ BP.n³45 Tabarka 8110, Tunisia
}

\begin{abstract}
Calicotome villosa and Genista spachiana are classified as vulnerable in Tunisia and they are of great interest for the rehabilitation of degraded ecosystems, food for goats and camelids, and for the use of its essential oils in phytotherapy. The aim of this study was to examine the germination characteristics of both species through analysis of the effects of the salt stress and water stress on germination. We monitored and evaluated different germination characteristics (germination percentage, mean time to germination and germination speed) in the presence of the salt and water stress. Calicotome villosa and Genista spachiana can withstand salinity of up to $15 \mathrm{~g} / \mathrm{l}$ of salt (31-37\% germination at $15 \mathrm{~g} / \mathrm{l}$ ) and also tolerate large doses of $\mathrm{PEG}_{6000}(30-40 \%$ germination at $-1.6 \mathrm{MPa}$ : Polyethylene glycol (PEG) is a hydrophilic polymer). The tolerance of the two species to salinity and water stress allows them to be a source of food for goats and camelids during drought.
\end{abstract}

Keywords: Calicotome villosa, Genista spachiana, arid land forage, salt stress, water stress

\section{INTRODUCTION}

Tunisia is among the countries most seriously affected by desertification. Accounting for three quarters of the country (Le Houérou, 1959), southern Tunisia is subdivided into: (i) the arid zone, which covers $5.5 \times 10^{4} \mathrm{~km}^{2}$ with average annual precipitations between 100 and $350 \mathrm{~mm}$, and (ii) the desert zone, which occupies an area of about $6.5 \times 10^{4} \mathrm{~km}^{2}$ with an annual average rainfall less than $100 \mathrm{~mm}$ (PNUD/FAO, 1979). One of the promising options for restoration of decertified regions in southern Tunisia is to use native shrub and tree species that have multiple functions in the ecosystem. Several

*Corresponding author. E-mail: jaouadiwahbi@gmail.com species of the legume family (Fabaceae) are of high interest due to their adaptation to arid and semiarid environments, nitrogen fixing capacity, and ability to grow in poor soils (Ibanez, Passera, 1997). Legumes are of great importance worldwide, especially in countries with a Mediterranean climate like Tunisia, since they contribute to soil fertility and prevention of soil erosion. Several native species of legumes are potentially useful for rehabilitation of degraded ecosystems, food for goats and camelids, and dune stabilization and vegetation. Calicotome villosa is very common in the Mediterranean area (Gibbs, 1968; Tutin, 1972). It is a tall $50-150 \mathrm{~cm}$ spiny shrub that produces yellow flowers in spring. It grows especially in North Africa and Spain (Greuter et al., 1989). The species has 
intricate, angular, pubescent branches that are green when young and become greyish when mature. It has alternate leaves: the lower leaves are elongate, oval, trifoliate, and covered with sericeous down. The flowers are yellow and have a bell-shaped calyx, thickly downy legume with a protuberant upper rib, and round dark olivaceous seeds. Genista spachiana is a shrub that reaches $1-1.5 \mathrm{~m}$ and is found in depressions of deep sandy soil. This species is a dominant perennial shrub in active sand dunes and stabilized sand fields in the southern arid zone of Tunisia.

Successful establishment of plants largely depends on successful germination. Germination is a crucial stage in the life cycle of plants and tends to be highly unpredictable over space and time (Camarada, Valsecchi, 1983). Several environmental factors including temperature, salinity, light, and soil moisture simultaneously influence germination (El-Keblawy and AlRawai, 2005, 2006; Huang et al., 2003; Ungar, 1995; Zia, Khan, 2004). Seed germination behaviour in relation to thermal and salt stress is a very important determinant of the colonization capacity of a species (Ungar, 1982, 1995). Tolerance to salinity during germination is critical for the establishment of plants growing in saline soil of arid regions (Khan, Gulzar, 2003; Ungar, 1995). Increased salinity leads to a reduction and/or delay in germination of seeds of both halophytes and glycophytes. Failure of germination in saline soils often is a result of high concentrations of salts in the seed-planting zone because of the upward movement of the soil solution and subsequent evaporation at the soil surface. Seed germination under saline conditions occurs after high precipitation, when soil salinity is usually reduced due to leaching and dilution (El-Keblawy, 2004; Huang et al., 2003; Khan, Ungar, 1996; Redondo et al., 2004). Although salinity and osmotic stress of arid environments decrease germination, the detrimental effect of salinity and osmotic stress are generally less severe at optimum germination temperature (Gorai, Neffati, 2007; Tlig et al., 2008; Gorai et al., 2009; Maraghni et al., 2010).

This study was conducted to better understand seed germination requirements of Calico- tome villosa and Genista spachianna. The effects of a wide range of salinity and drought levels on the germination percentage, speed rate (velocity), and mean time to germination of three provenances of each species were studied to determine their individual effect and the interaction between these factors on germination.

\section{MATERIALS AND METHODS}

\section{Plant Material}

Seeds of Calicotome villosa were collected in 2013 from two natural habitats, namely Meknassi and Bouhedma, while seeds of Genista spachianna were collected from Rtiba. Seeds of the three provenances differ in morphology (Table 1). Before the germination tests, damaged and insect-infected seeds were discarded, and the empty ones were eliminated using floatation in distilled water. Seeds were separated from fruits and soaked in water for $24 \mathrm{~h}$. These seeds were sterilised with Benlate $(1 \mathrm{~g} / \mathrm{l})$ for 20 min and then with $50 \%$ sodium hypochlorite for a few minutes and rinsed three times with distilled water.

\section{Salinity and drought treatments}

To determine the tolerance of germination under the salt stress, seeds were sown in $\mathrm{NaCl}$ solution at different concentration: 0 (distilled water), 3, 6, 9, 12, and $15 \mathrm{~g}$ of $\mathrm{NaCl}$ added to one litre of distilled water. The water-stress treatments used were 0 (control), $-0.03,-0.1,-0.7$, -1 , and $-1.6 \mathrm{MPa}$ obtained by adding $\mathrm{PEG}_{6000}$ to one litre of distilled water. Seeds were placed in sterile Petri dishes with two discs of filter paper saturated with distilled water for control and with $\mathrm{NaCl}$ solutions for treatments. $\mathrm{NaCl}$ solutions were renewed every $48 \mathrm{~h}$ under sterile conditions in order to avoid salt accumulation (Rahman et al., 2008). Five replicates of 20 seeds each were used for each treatment with $10 \mathrm{ml}$ of test solution. Seeds were allowed to germinate in relative humidity of $80 \%$ at $25^{\circ} \mathrm{C}$ in complete darkness for 30 days (Maraghni et al., 2010). A seed was considered to have germinated when the emerging radicle elongated to $2 \mathrm{~mm}$ (Redondo-Gomez et al., 2007). 
Table 1. Morphological diversity of seeds and climate variability of the three provenances

\begin{tabular}{|c|c|c|c|c|c|}
\hline Seeds & $\begin{array}{l}\text { Biocli- } \\
\text { matic }\end{array}$ & $\begin{array}{c}\text { Annual } \\
\text { rainfall } \\
(\mathrm{mm})\end{array}$ & $\begin{array}{c}\text { Temperature } \\
\left({ }^{\circ} \mathrm{C}\right)\end{array}$ & $\begin{array}{l}\text { Type of } \\
\text { soil }\end{array}$ & Seed morphology \\
\hline $\begin{array}{c}\text { Seeds of Calicotome } \\
\text { villosa of Meknessi } \\
\text { site (north of Saharan } \\
\text { Atlas chain) }\end{array}$ & arid & $200-350$ & $\begin{array}{l}25-30^{\circ} \mathrm{C} \text { in } \\
\text { summer and } \\
5 \text { to } 10^{\circ} \mathrm{C} \text { in } \\
\text { winter }\end{array}$ & $\begin{array}{l}\text { Calcare- } \\
\text { ous soil }\end{array}$ & \\
\hline $\begin{array}{c}\text { Seeds of Calicotome } \\
\text { villosa of Bouhedma } \\
\text { site (south of Saharan } \\
\text { Atlas chain) }\end{array}$ & arid & $100-200$ & $\begin{array}{l}32-36{ }^{\circ} \mathrm{C} \\
\text { in summer } \\
\text { and } 4 \text { to } 7{ }^{\circ} \mathrm{C} \\
\text { in winter }\end{array}$ & $\begin{array}{c}\text { Sandy } \\
\text { soil }\end{array}$ & \\
\hline $\begin{array}{c}\text { Seeds of Genista } \\
\text { spachiana of Rtiba } \\
\text { site (north of Dorsal } \\
\text { chain). }\end{array}$ & subhumid & $500-700$ & $\begin{array}{l}15-25^{\circ} \mathrm{C} \text { in } \\
\text { summer and } \\
2 \text { to } 5^{\circ} \mathrm{C} \text { in } \\
\text { winter }\end{array}$ & $\begin{array}{c}\text { Sandy } \\
\text { soil }\end{array}$ & \\
\hline
\end{tabular}

\section{Methods of germination expression}

Mean time to germination (MTG) calculated as follows:

$$
\mathrm{MTG}=\sum n_{i} \times d_{i} / n
$$

where " $n$ " is the total number of germinated seeds during the test, " $n_{i}$ " is the number of germinated seeds on day " $d_{i}$ ", and " $i$ " is the number of days during the germination period (between 0 and 30 days) (Yousheng, Sziklai, 1985). Germination counts were performed daily for 30 days. Cumulative germination percentage (GP \%) was evaluated daily and the final value was obtained after 30 days and Kotowski's coefficient (CV) was calculated according to this method:

$$
\mathrm{CV}=\Sigma(n \times J n) / \sum n
$$

where " $n$ " is the total number of germinated seeds during the test, " $n$ " is the number of days during the germination period (between 0 and 30 days).

\section{Statistical analysis}

Germination data were arcsine transformed before statistical analysis to ensure homogeneity of variance. Data were analysed using SPSS for Windows, version 11.5 (SPSS, 2002). A twoway analysis of variance (ANOVA) was carried out to test the effects of main factors (effect of salinity on the provenance and effect of drought on the provenance) and their interaction on the final germination percentage. Tukey HSD test was used to estimate significant differences between means.

\section{RESULTS}

\section{Effects of salt stress on seed germination}

Salinity significantly $(P<0.0001)$ affected the percentage of germination of Calicotome villosa and Genista spachianna (Table 2). 
Table 2. Mean germination percentage of Calicotome villosa and Genista spachianna seeds after transfer from $0,3,6,9,12$, and $15 \mathrm{~g} / 1 \mathrm{NaCl}$ at $25^{\circ} \mathrm{C}$. Data are means $\pm \mathrm{SE}$. Different letters indicate significant differences between treatments $(\mathrm{NaCl})$ at $P<0.05$ according to the Tukey test

\begin{tabular}{c|c|c|c|c|c|c}
\hline \multirow{2}{*}{ Species } & \multicolumn{5}{c}{$\mathrm{NaCl}(\mathrm{g} / \mathrm{l})$} & 9 \\
\cline { 2 - 7 } & $\mathbf{0}$ & 3 & 6 & 12 & 15 \\
\hline $\begin{array}{c}\text { Calicotome villosa } \\
\text { of Meknassi }\end{array}$ & $75 \pm 10.840^{\mathrm{a}}$ & $60 \pm 3.162^{\mathrm{ab}}$ & $49 \pm 7.649^{\mathrm{ab}}$ & $50 \pm 6.124^{\mathrm{ab}}$ & $47 \pm 2.550^{\mathrm{ab}}$ & $32 \pm 7.517^{\mathrm{b}}$ \\
\hline $\begin{array}{c}\text { Calicotome villosa } \\
\text { of Bouhedma }\end{array}$ & $78 \pm 13.748^{\mathrm{a}}$ & $51 \pm 8.276^{\mathrm{ab}}$ & $48 \pm 6.819^{\mathrm{ab}}$ & $41 \pm 5.339^{\mathrm{b}}$ & $35 \pm 4.743^{\mathrm{b}}$ & $31 \pm 7.969^{\mathrm{b}}$ \\
\hline $\begin{array}{c}\text { Genista spachianna } \\
\text { of Rtiba }\end{array}$ & $82 \pm 15.133^{\mathrm{a}}$ & $61 \pm 7.969^{\mathrm{ab}}$ & $60 \pm 4.472^{\mathrm{ab}}$ & $56 \pm 6.595^{\mathrm{ab}}$ & $42 \pm 3.742^{\mathrm{b}}$ & $37 \pm 5.385^{\mathrm{b}}$ \\
\hline
\end{tabular}

a, b,c Values in the same row with the same superscript are not significantly different $(P>0.05)$.

Germination in distilled water was the highest. However, it decreased significantly with an increase in $\mathrm{NaCl}$ concentrations (Fig. 1). Seeds germinated rapidly in distilled water during the first five days; however, germination was delayed to eight days at concentrations greater than $3 \mathrm{~g} / \mathrm{l}$. The highest germination percentage was in distilled water followed by $3,6,9$, 12 and $15 \mathrm{~g} / \mathrm{l} \mathrm{NaCl}$. There was a strong negative relationship between germination and salinity. The germination velocity calculated using the Kotowski coefficient showed that the rate decreased with an increase in salinity (Fig. 2). The results of the ANOVA showed that the salt stress ( $\mathrm{NaCl}$ treatments) had a significant effect $(P<0.001)$ on the germination percentage and on mean germination time (Table 3 ).
Germination was significantly reduced by high $\mathrm{NaCl}$ levels and there were no great differences in the final germination percentage between 3 and $9 \mathrm{~g} / \mathrm{l}$, thus the germination percentage was reduced with increasing $\mathrm{NaCl}$ to levels above $12 \mathrm{~g} / \mathrm{l}$ (Tukey's multiple test). A two-way ANOVA of the germination rate indicated a significant effect of salinity but not an interaction between species and salinity (Table 3 ).

\section{Effects of osmotic potential on germination}

Osmotic potential significantly $(P<0.001)$ affected the percentage of germination of Calicotome villosa and Genista spachianna (Table 4), which was highest in distilled water. However, the germination percentage decreased significantly with an increase in osmotic potential.

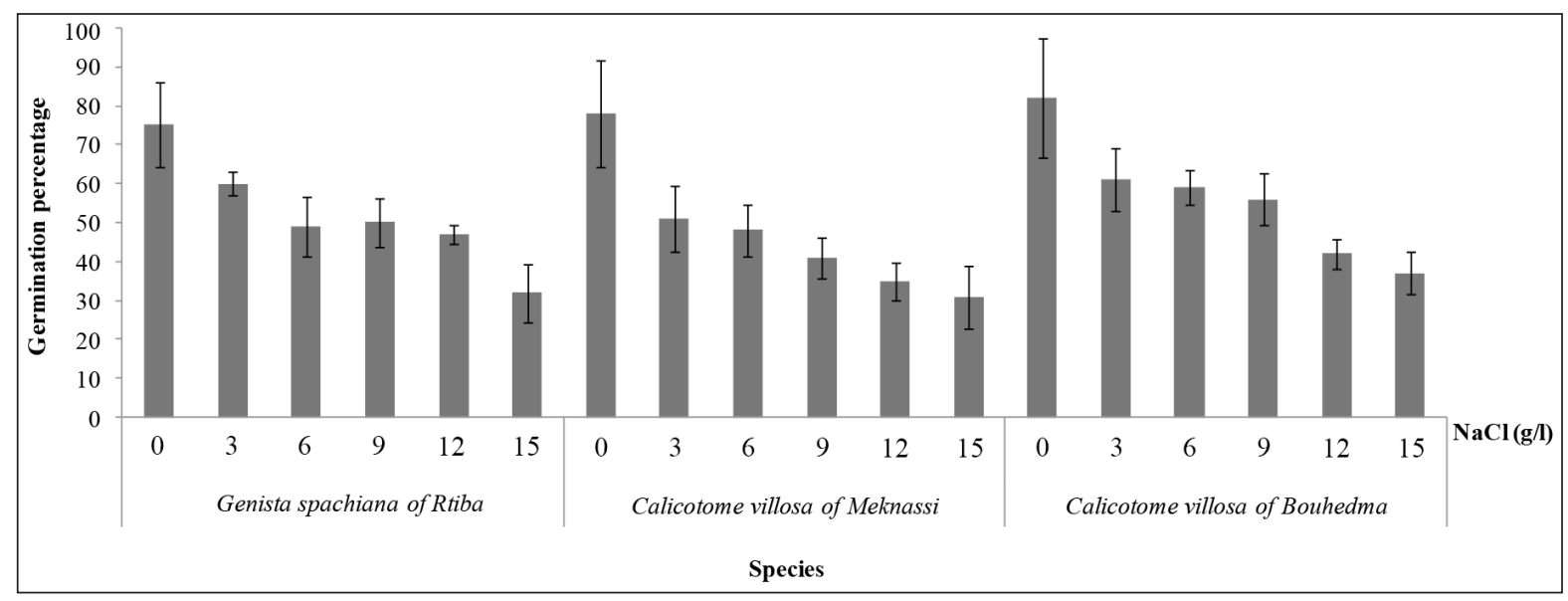

Fig. 1. Mean germination percentage of Calicotome villosa and Genista spachianna seeds in various $\mathrm{NaCl}$ concentrations $(0,3,6,9,12$, and $15 \mathrm{~g} / \mathrm{l})$ at $25^{\circ} \mathrm{C}$. Values (mean $\pm \mathrm{SEM}$ ) 


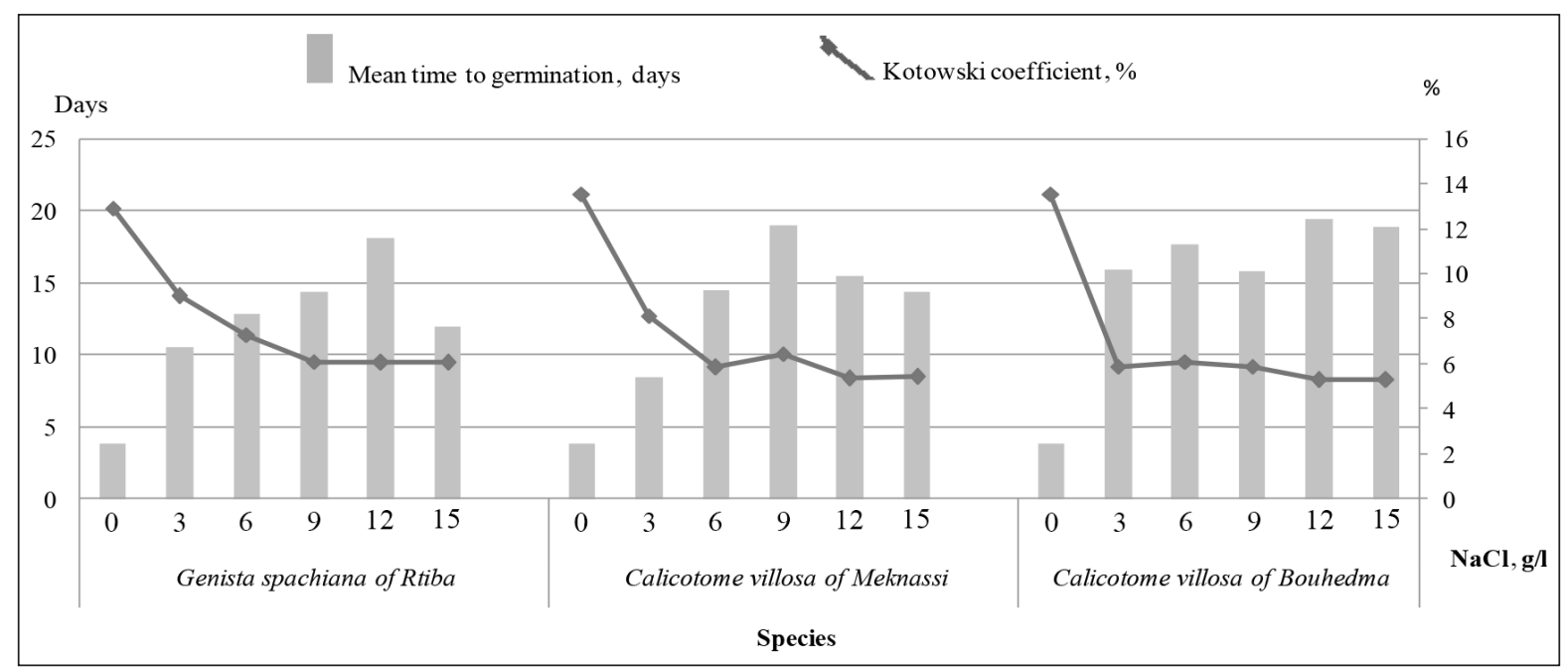

Fig. 2. Mean time to germination and Kotowski coefficient of Calicotome villosa and Genista spachianna seeds in various $\mathrm{NaCl}$ concentrations $(0,3,6,9,12$, and $15 \mathrm{~g} / \mathrm{l})$ at $25^{\circ} \mathrm{C}$

Table 3. Two-way ANOVA of the effects of salinity (S), species (T), and their interaction on germination characteristics of Calicotome villosa and Genista spachianna

\begin{tabular}{c|c|c|c|c}
\hline Variable & Characteristics of germination & $F$-value & $P$-value & Signification \\
\hline \multirow{3}{*}{ Species } & Germination percentage & 1.985 & 0.145 & NS \\
& Kotowski coefficient & 0.591 & 0.557 & NS \\
& Mean time to germination & 4.976 & 0.009 & ${ }^{* *}$ \\
\hline \multirow{3}{*}{ Concentration } & Germination percentage & 11.673 & $\mathbf{0 . 0 0 0}$ & $* * *$ \\
& Kotowski coefficient & 12.503 & $\mathbf{0 . 0 0 0}$ & $* * *$ \\
& Mean time to germination & 29.097 & $\mathbf{0 . 0 0 0}$ & $* * *$ \\
\hline \multirow{3}{*}{ Species * Concentration } & Germination percentage & 0.225 & 0.993 & NS \\
& Kotowski coefficient & 0.234 & 0.992 & NS \\
& Mean time to germination & 1.259 & 0.270 & NS \\
\hline
\end{tabular}

Significant difference from control at ${ }^{*} P<0.05,{ }^{* *} P<0.01,{ }^{* *} P<0.001$ by Tukey's multiple test. NS $=$ not significant $(P>0.05)$.

Table 4. Mean germination percentage of Calicotome villosa and Genista spachianna seeds after their transfer from $0,-0.03,-0.1,-0.7,-1$, and $-1.6 \mathrm{MPa}$ at $25^{\circ} \mathrm{C}$. The data are means \pm SE. Different letters indicate significant differences between treatments (osmotic potential) at $P<0.05$ according to the Tukey's multiple test

\begin{tabular}{c|c|c|c|c|c|c}
\hline \multirow{2}{*}{ Species } & \multicolumn{5}{c}{ Osmotic potential (MPa) } \\
\cline { 2 - 7 } & $\mathbf{0}$ & $-\mathbf{0 . 0 3}$ & -0.1 & -0.7 & -1 & -1.6 \\
\hline $\begin{array}{c}\text { Calicotome villosa } \\
\text { of Bouhedma }\end{array}$ & $78 \pm 4.062^{\mathrm{a}}$ & $65 \pm 10.840^{\mathrm{ab}}$ & $65 \pm 8.944^{\mathrm{ab}}$ & $56 \pm 3.674^{\mathrm{abc}}$ & $41 \pm 9.407^{\mathrm{bc}}$ & $30 \pm 4.743^{\mathrm{c}}$ \\
\hline $\begin{array}{c}\text { Calicotome villosa } \\
\text { of Meknassi }\end{array}$ & $74 \pm 4.848^{\mathrm{a}}$ & $79 \pm 4.359^{\mathrm{a}}$ & $65 \pm 6.892^{\mathrm{ab}}$ & $56 \pm 6.595^{\mathrm{ab}}$ & $43 \pm 8.746^{\mathrm{c}}$ & $38 \pm 7.517^{\mathrm{c}}$ \\
\hline $\begin{array}{c}\text { Genista spachi- } \\
\text { anna of Rtiba }\end{array}$ & $78 \pm 4.062^{\mathrm{a}}$ & $65 \pm 6.892^{\mathrm{ab}}$ & $55 \pm 4.743^{\mathrm{ab}}$ & $48 \pm 8.746^{\mathrm{ab}}$ & $42 \pm 9.566^{\mathrm{c}}$ & $40 \pm 9.618^{\mathrm{c}}$ \\
\hline
\end{tabular}

$\overline{\mathrm{a}, \mathrm{b}, \mathrm{c}}$ Values in the same row with the same superscript are not significantly different $(P>0.05)$. 
Seeds germinated rapidly in distilled water during the initial first days; however, the start of germination was delayed for 10 days at concentrations than $3 \mathrm{~g} / \mathrm{l}$ (Fig. 3).

Delay in germination increased with increasing osmotic potential (Fig. 4). The highest germination percentage was in distilled water followed by $0,-0.03,-0.1,-0.7,-1$, and $-1.6 \mathrm{MPa}$. However, at -0.03 MPa Calicotome villosa seeds from Meknassi had a germination rate higher than that at $0 \mathrm{MPa}$. There was a strong negative relationship between the germination percentage and the osmotic potential for both species. The Kotowski coefficient showed that the rate decreased with an increase in osmotic potential. For all three provenances to Calicotome villosa and Genista spachianna, the water stress (PEG) had a significant effect $(P<0.001)$ on the germination percentage, mean germination time (MGT) and the Kotowski coefficient (Table 4). The germination percentage and speed decreased with a decrease in water potential, this decrease was significant at lower $-1 \mathrm{Mpa}$. The germination percentage for Calicotome seeds from Meknassi was the highest among all treatments ( 79 was at $0.03 \mathrm{MPa}$ ). Also, the germination percentage exceeded $50 \%$ at $-1 \mathrm{MPa}$. A two-way ANOVA indicated a significant

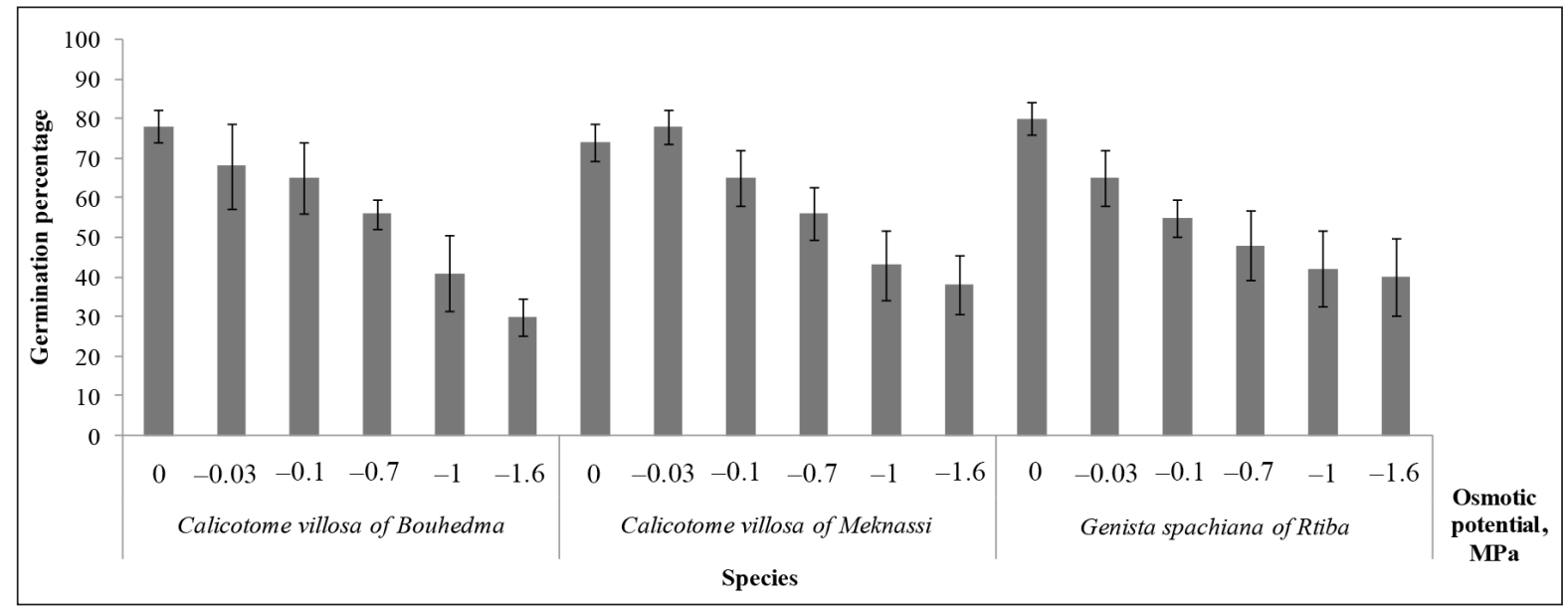

Fig. 3. Mean germination percentage of Calicotome villosa and Genista spachianna seeds in various osmotic potentials $(0,-0.03,-0.1,-0.7,-1$, and $-1.6 \mathrm{MPa})$ at $25^{\circ} \mathrm{C}$. Values (mean $\pm \mathrm{SEM}$ )

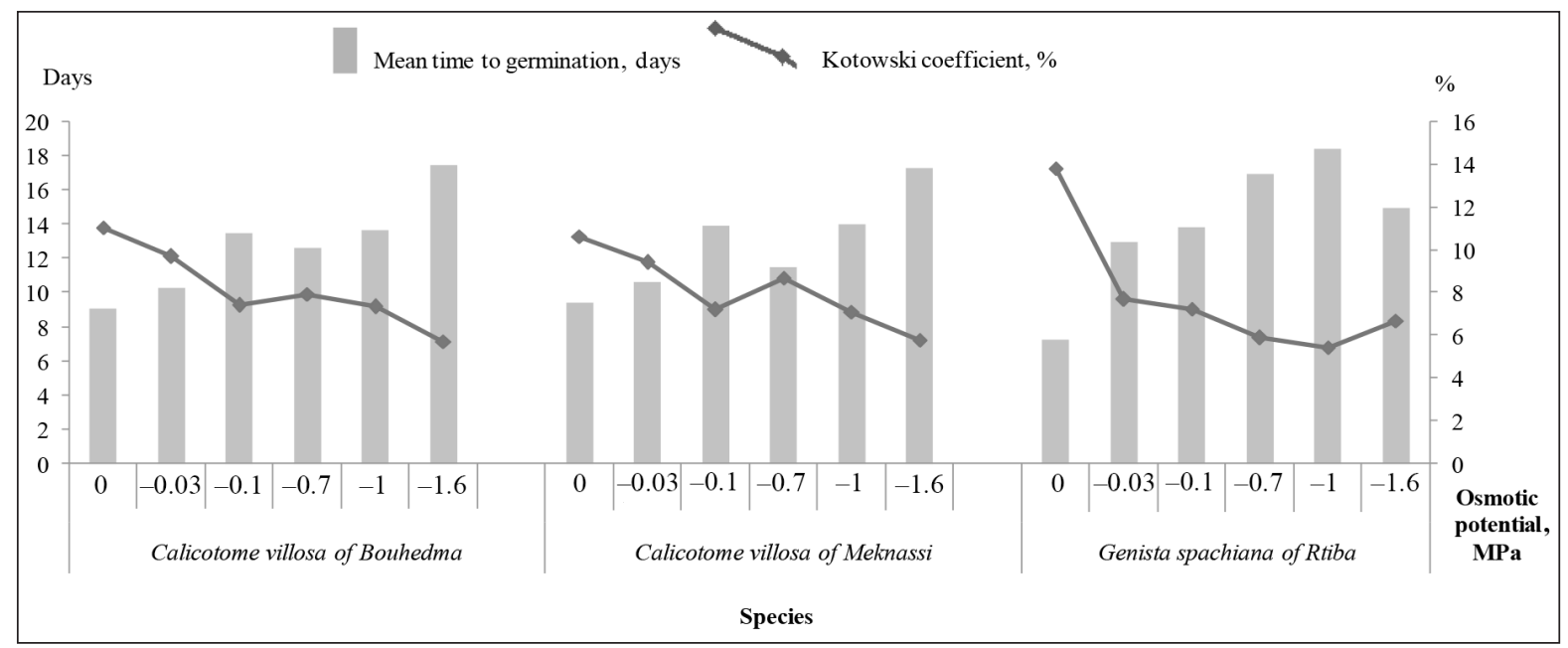

Fig. 4. Mean time to germination and Kotowski coefficient of Calicotome villosa and Genista spachianna seeds in various osmotic potentials $(0,-0.3,-0.1,-0.7,-1,-1.6 \mathrm{MPa})$ at $25^{\circ} \mathrm{C}$ 
effect of osmotic potential on the germination rate, but not for the interaction between osmotic potential and species germination percentage (Table 5).

\section{DISCUSSION}

Salinity stress can affect seed germination through osmotic effects (Welbaum et al., 1990) and by ion-toxicity (Huang and Reddman, 1995). More than 50\% of the seeds of Calicotome villosa and Genista spachianna germinated at the lowest salinity stress $(9 \mathrm{~g} / \mathrm{l})$ and at the lowest water potential $(-1 \mathrm{MPa})$. This suggested that this species can germinate under low water availability. Other study demonstrated that even the seeds of such desert species as Ziziphus lotus at a germination rate of $5 \%$ at -1 MPa. (Maraghni et al., 2010). Ibanez and Passera (1997) found that Anthyllis cystoides seeds germinated at $-1.12 \mathrm{MPa}(48 \%)$. Similar results were reported for other fabaceae species like Acacia tortilis which had no germinated seeds at $-0.8 \mathrm{MPa}$ (Jaouadi et al., 2010). This tolerance of water potential $(-0.8 \mathrm{MPa})$ was also observed in other Fabaceae and desert species like Retama raetam (Youssef, 2009).

Generally, the salt stress affected the germination capacity and speed of Calicotome and Genista seeds, and these results agree with these of Lachiheb et al., (2004). In our study, seed germination percentage was higher in $\mathrm{NaCl}$ than in PEG at the same water potential. $\mathrm{He}$ et al. (2009), demonstrated that $\mathrm{NaCl}$ and PEG adversely affected germination, but $\mathrm{NaCl}$ had a less inhibitory effect on seed germination than an iso-osmotic solution of PEG. In contrast, Katembe et al. (1998) found that higher concentrations of $\mathrm{NaCl}(-1 \mathrm{MPa})$ were more inhibitory to germination of two Atriplex species (A. halunus and A. numelaria). Seeds of Calicotome villosa and Genista spachianna responded to salinity in two characteristic ways: first, germination was reduced, and second, at very low concentrations, germination was stimulated. Although higher salinity generally decreases germination, the detrimental effect of salinity is less severe at the optimum germination osmotic potential. The salt stress decreased both the rate and percentage of germination of Calicotome villosa and Genista spachianna, which agrees with several other studies revealing that halophytes, as well as glycophytes, are sensitive to salt during the germination stage (Ungar, 1995; Katembe et al., 1998; Khan et al., 2002; Gorai, Neffati, 2007; Gorai et al., 2011). Considering the percentage of seeds that germinated at $-1 \mathrm{MPa}$ and $12 \mathrm{~g} / \mathrm{l}$, we conclude that these two fabaceae species are well adapted to germinate under conditions of water and salt stresses. These abiotic stresses are typical of the environments in which they grow. The arid

Table 5. A two-way ANOVA of the effects of Osmotic potential (S), Species (T), and their interaction on germination characteristics of Calicotome villosa and Genista spachianna

\begin{tabular}{|c|c|c|c|c|}
\hline Variable & Characteristics of germination & F-value & P-value & Signification \\
\hline \multirow[t]{3}{*}{ Species } & Germination percentage & 0.570 & 0.568 & NS \\
\hline & Kotowski coefficient & 3.782 & 0.027 & * \\
\hline & Mean time to germination & 5.040 & 0.009 & ** \\
\hline \multirow[t]{3}{*}{ Concentration } & Germination percentage & 14.051 & 0.000 & $* * *$ \\
\hline & Kotowski coefficient & 6.330 & 0.000 & $* * *$ \\
\hline & Mean time to germination & 14.731 & 0.000 & $* * *$ \\
\hline \multirow[t]{3}{*}{ Species ${ }^{\star}$ Concentration } & Germination percentage & 0.436 & 0.924 & NS \\
\hline & Kotowski coefficient & 0.766 & 0.661 & NS \\
\hline & Mean time to germination & 2.340 & 0.019 & $*$ \\
\hline
\end{tabular}

Significant difference from control at ${ }^{\star} P<0.05,{ }^{* *} P<0.01,{ }^{\star * \star} P<0.001$ by Tukey's multiple test. NS $=$ not significant $(P>0.05)$. 
lands of Tunisia are widely affected bydesertification caused particularly by the degradation of the vegetation cover, deforestation, and drought.

The high ability of Calicotome villosa and Genista spachiana to germinate over a wide range of environmental conditions provides an opportunity to contribute to future reforestation programmes. Calicotome villosa seeds from Meknassi had a higher rate of germination at $-0.03 \mathrm{MPa}$ than at $0 \mathrm{MPa}$ compared with non-stressed seeds. Seed germination percentage and the Kotowski coefficient generally decreases as soil water potential decreases (Evans, Etherington, 1990; Oberbauer, Miller, 1982), either by drying or by higher salinity. By increasing water stress, similar results were found for germination of Diospyros texana seeds that decreased from about $95 \%$ at $0 \mathrm{MPa}$ to $45 \%$ at $-0.6 \mathrm{MPa}$ (Everitt, 1984). On the other hand, germination of three deciduous semi-shrubs of Artemisia was inhibited severely in $\mathrm{PEG}_{6000}$ solutions at $-1.2 \mathrm{MPa}$ (Tobe et al., 2006). An increase in osmolality of $\mathrm{PEG}_{6000}$ solutions results in decreasing both the percentage and the rate of germination Calicotome villosa and Genista spachianna, indicating that the water stress inhibits germination, which is in agreement with the germination behaviour of most species (Tobe et al., 2006; Gorai et al., 2009; Maraghni et al., 2010). It can be concluded that seeds of Calicotome villosa and Genista spachiana have the ability to tolerate the salt stress after exposure to $\mathrm{NaCl}$ solutions and osmotic potential concentrations. Further investigations are necessary to understand the early establishment of this species under field conditions and to determine if there are differences between the seed germination stage and early seedling growth in response to salinity and drought stress.

\section{CONCLUSIONS}

Our work demonstrated a relationship between germination properties of seeds and abiotic constraints in Calicotome villosa and Genista spachiana. Genista spachiana is most tolerant to the salt stress in a concentration of $12 \mathrm{~g} / \mathrm{l}$. The germination rate of two Calicotome villosa provenances and Genista spachiana decreases with increasing concentrations of PEG. The water stress affects the germination rate and increases the time required for seed germination of two Calicotome villosa and Genista spachiana. Even at high concentrations of PEG, seeds of the two species germinated to $30 \%$ to $40 \%$. Thus, the species tolerate drought and harsh climatic conditions of the environment. The Genista spachiana provenance from Rtiba is more tolerant to water deficit than the Calicotome villosa provenance, with the germination rate of $40 \%$ at the water potential of $-1.6 \mathrm{MPa}$.

Received 20 September 2016 Accepted 1 January 2017

\section{References}

1. Badger KS, Ungar IA. The effects of salinity and temperature on the germination of the inland halophyte Hordeum jubatum. Canadian Journal of Botany. 1989; 67: 1420-5.

2. Bayuelo-Jiménez JS, Debouck DG, Lynch JP. Salinity tolerance of Phaseolus species during germination and early seedling growth. Crop Science. 2002; 42: 1584-94.

3. Camarda I, Valsecchi F. Alberie arbus tispontanei della Sardegnaed. Gallizzi, Sassari: 403412. 1983.

4. El-Keblawy A, Al-Rawai A. Effects of salinity, temperature and light on germination of invasive Prosopis juliflora (Sw) D.C. J. Arid Environ 2005 ; 6: 555-65.

5. El-Keblawy A. Salinity effects on seed germination of the common desert range grass, Panicum turgidum. Seed Science and Technology. 2004; 32: 943-8.

6. El-Keblawy A, Al-Rawai A. Effects of seed maturation time and dry storage on light and temperature requirements during germination in invasive Prosopis juliflora. Flora. 2006; 20: $135-43$. 
7. Evans C, Etherington JR. The effect of soil water potential on seed germination of some British plants. New Phytologist. 1990; 115: 539-48.

8. Everitt BS. Introduction to latent variable models. London: Chapman and Hall; 1984. $107 \mathrm{p}$.

9. Gibbs PE. Taxonomy and distribution of the genus Calicotome. Notes From Royal Botanic Garden. 1968; 28: 275-86.

10. Gorai M, Gasmi H, Neffati M. Factors influencing seed germination of medicinal plant Salvia aegyptiaca L. (Lamiaceae). Saudi Journal of Biological Sciences. 2011; 18: 255-60.

11. Gorai M, Neffati M. Germination responses of Reaumuria vermiculata to salinity and temperature. Ann. Appl. Biol. 2007; 151: 53-9.

12. Gorai M, Tlig T, Neffati M. Influence of water stress on seed germination characteristics in invasive Diplotaxis harra (Forssk.) (Brassicaceae) in arid zone of Tunisia. Journal of Phytology. 2009; 1: 249-54.

13. Gorai M, Vadel MA, Neffati M. Seed germination characteristics of Phragmites communis: effects of temperature and salinity. Belg. J. Bot. 2006; 139: 78-86.

14. Greuter W, Burdet HM, Long G. Med-Checklist: a critical inventory of vascular plants of the circum-mediterranean countries. Dicotyledones (Lauraceae-Rhamnaceae). Vol. 4. Geneva, Switzerland; 1989.

15. He Xq, Du C, Shao Z, Li Q. Effect of salt and water stress on seed germination of Dianthus chinensis L. Academic conference on horticultural science and technology proceedings. 2009; 12: 60-62.

16. Huang J, Reddman RE. Salt tolerance of Hordeum and Brassica species during germination and early growth. Can. J. Plant Sci. 1995; 75: 815-819.

17. Huang ZY, Zhang XS, Zheng GH, Gutterman Y. Influence of light, temperature, salinity and storage on seed germination of Haloxylon ammodendron. J. Arid Environ. 2003; 55: 453-64.
18. Ibanez AN, Passera CB. Factors affecting the germination of albaida (Anthyllis cytisoides L.), a forage legume of the Mediterranean coast. J. Arid Environ. 1997; 35: 225-31.

19. Jaouadi W, Hamrouni L, Souayeh N, Khouja ML. Étude de la germination des graines d'Acacia tortilis sous différentes contraintes abiotiques. Biotechnologie Agronomie Société Environnement. 2010; 14: 643-52.

20. Katembe WJ, Ungar IA, Mitchell JP. Effect of salinity on germination and seedling growth of two Atriplex species. Ann. Bot. 1998; 82: 167-71.

21. Khan MA, Gul B, Weber DJ. Germination responses of Salicornia rubra to temperature and salinity. J. Arid Environ. 2000; 45: 207-14.

22. Khan MA, Gul B, Weber DJ. Seed germination in relation to salinity and temperature in Sarcobatus vermiculatus. Biologia Plantarum. 2002; 45: 133-5.

23. Khan MA, Gulzar S. Germination responses of Sporobolus ioclados: a saline desert grass. J. Arid Environ. 2003; 53: 387-94.

24. Khan MA, Rizvi Y. Effect of salinity, temperature, and growth regulators on the germination and early seedling growth of Atriplex griffithii var. stocksii. Can. J. Bot. 1994; 72: 475-9.

25. Khan MA, Ungar IA. Seed polymorphism and germination responses to salinity stress in Atriplex triangularis Willd. Botanical Gazette. 1984; 145: 487-94.

26. Khan MA, Ungar IA. Alleviation of seed dormancy in the desert forb Zygophyllum simplex L. from Pakistan. Ann. Bot. 1997; 80: 395-400.

27. Khan MA, Ungar IA. Seed germination and dormancy of Polygonum aviculare L. as influenced by salinity, temperature, and gibberellic acid. Seed Science and Technology. 1998; 26: 107-17.

28. Lachiheb K, Neffati M, Zid E. Aptitudes germinatives de certaines graminées halophytes spontanées de la Tunisie méridionale. Cahiers OPTIONS méditerranéennes. 2004; 62: 89-93.

29. Le Houérou HN. Recherches écologiques et floristiques sur la végétation de la Tunisie 
méridionale. Institut des recherches sahariennes, Alger. 1959. 229 p.

30. Maraghni M, Gorai M, Neffati M. Seed germination at different temperatures and water stress levels, and seedling emergence from different depths of Ziziphus lotus. South African Journal of Botany. 2010; 76: 453-9.

31. Oberbauer S, Miller PC. Effect of water potential on seed germination. Holarct. Ecol. 1982; 5: 218-20.

32. Ourcival JM, Berger A. Equilibrium between soil water potential and predawn water potential of two pre-saharan shrub species of Tunisia. J. Arid Environ. 1995; 30: 175-83.

33. Redondo S, Rubio-Casal AE, Castillo JM, Luque CJ, Alvarez AA, Luque T, Figueroa ME. 2004. Influences of salinity and light on germination of three Sarcocornia taxa with contrasted habitats. Aquat. Bot. 78: 255-64.

34. Redondo-Gómez S, Mateos-Naranjo E, Davy AJ, Fernández-Muñoz F, Castellanos EM, Luque T. Growth and photosynthetic responses to salinity of the salt-marsh shrub Atriplex portulacoides. Ann. Bot. 2007; 100: 555-63.

35. Song J, Feng G, Tian C, Zhang F. Strategies for adaptation of Suaeda physophora, Haloxylon ammodendron and Haloxylon persicumto to saline environment during seed germination stage. Ann. Bot. 2005; 96: 399-405.

36. Tlig T, Gorai M, Neffati M. Germination responses of Diplotaxis harra to temperature and salinity. Flora. 2008; 203: 421-8.

37. Tobe K, Li XM, Omasa K. Effects of sodium chloride on seed, germination and growth of two Chinese desert shrubs, Haloxylon ammodendron and Haloxylon persicum (Chenopodiaceae). Aust. J. Bot. 2000; 48: 455-60.

38. Tutin GT, editor. Flora Europea. Cambridge University Press; 1972.

39. Ungar IA. Germination ecology of halophytes. In: Sen, DN, Rajpurohit, KS, editors. Contribution to the ecology of halophytes. Hague: Junk; 1982. p. 143-54.

40. Ungar IA. Seed germination and seed-bank ecology of halophytes. In: Kigel J, Galili G, edi- tors. Seed development and germination. New York: Marcel Dekker; 1995. p. 599-627.

41. Welbaum GE, Tissaoui T, Bradford KJ. Water relations of seed germination in muskmelon (Cucumis melo L.): III. Sensitivity of germination to water potential and abscisic acid during development. Plant Physiol. 1990; 92: 1029-37.

42. Youssef AM. Seed germination of some desert plants from Egypt. Journal of Applied Sciences Research. 2009. 5(2): 144-50.

43. Zia S, Khan MA. Effect of light, salinity, and temperature on seed germination of Limonium stocksii. Can. J. Bot. 2004; 82: 151-7.

\section{Mechergui Kaouther, Jaouadi Wahbi, Khouja Mohamed Larbi}

\section{GANYKLINIŲ AUGALŲ NAUDOJIMAS ATKURIANT NUALINTĄ ŽEMĘ TUNISE: CALICOTOME VILLOSA IR GENISTA SPACHIANA (FABACEAE)}

\section{Santrauka}

Calicotome villosa ir Genista spachiana yra klasifikuojami kaip pažeidžiami augalai Tunise. Jie yra labai svarbūs atkuriant nualintas ekosistemas, maitinant ožkų ir kupranugarinių šeimos gyvūnus, taip pat fitoterapijai naudojant eterinius aliejus. Buvo tiriamos abiejų rūšių daigumo savybès (daigumo procentas, vidutinis sudygimo laikas, dygimo greitis) druskingumo ir vandens stygiaus sukelto streso sąlygomis. Calicotome villosa ir Genista spachiana gali atlaikyti iki $15 \mathrm{~g} / 1$ druskingumą (31-37 \% daigumas esant $15 \mathrm{~g} / \mathrm{l}$ druskos), taip pat toleruoja dideles PEG $_{6000}$ dozes (30-40 \% daigumas esant 1,6 MPa: polietilenglikolis (PEG) yra hidrofilinis polimeras). Šių dviejų augalų rūšių tolerancija druskingumo ir vandens stygiaus sukeltam stresui leidžia augalams būti ožkų ir kupranugarinių šeimos gyvūnų maisto šaltiniu sausros metu.

Raktažodžiai: Calicotome villosa, Genista spachiana, sausringos žemès pašaras, druskingumo ir vandens stygiaus sukeltas stresas 